\title{
APPLICATION OF THE ISLAMIC LAW OF SUCCESSION IN SOUTH AFRICA
}

\author{
Muneer Abduroaf \\ LLB (Shariah) LLB LLM LLD \\ Lecturer, Department of Criminal Justice and \\ Procedure, University of the Western Cape
}

\section{SUMMARY}

Muslims have been living in South Africa for over 300 years. There are over 750000 Muslims living in South Africa today. These persons constitute a minority religious group in a non-Muslim country. Muslims are required in terms of their religion to follow Islamic law. There has (to date) been no legislation enacted by the South African parliament that gives effect to Islamic law. South African Muslims can however make use of existing South African law provisions in order to apply certain Islamic laws within the South African context. This article looks at the practical application of the Islamic law of succession and administration of estates within the South African context by way of a fictitious scenario. It highlights some of the problem areas when a Muslim testator or testatrix bequeaths his or her estate in terms of Islamic law by means of a will (Islamic will).

\section{INTRODUCTION}

Muslims have been living in South Africa for over 300 years. ${ }^{1}$ There are currently approximately over 750000 Muslims living in South Africa. ${ }^{2}$ They are a minority religious group in a non-Muslim country. Muslims are required in terms of their religion to follow Islamic law. There has (to date) been no legislation enacted by the South African parliament that gives effect to Islamic law. South African Muslims can make use of existing South African law provisions in order to apply certain Islamic laws within the South African context. This article looks at the practical application of the Islamic law of succession and administration of estates within the South African context by way of a fictitious scenario. It highlights some of the problem areas when a Muslim testator or testatrix bequeaths his or her estate in terms of Islamic law by means of a will (Islamic will). Four aspects are looked at in this regard, namely the Islamic will, the Islamic distribution certificate,

The first recorded Muslim arrived in South Africa in 1654. See Mahida History of Muslims in South Africa: A Chronology (1993) 1.

2 Statistics South Africa "Census 2001 Primary Tables South Africa 96 and 2001 Compared" http://www.statssa.gov.za/census01/html/RSAPrimary.pdf (accessed 2015-01-03). It should be noted that religion has not formed part of the published censuses since 2001. 
interpretation of the Islamic will and the Islamic distribution certificate, and possible constitutional challenges to provisions found in the Islamic law of intestate succession. The scenario that is looked at in this article is where a person (X) dies on 30 August 2017 at 10:00 PM at the age of 45 due to a gunshot wound that caused his death. He died six hours after being shot. He was shot at 4:00 PM. The time of his death was confirmed by a registered medical doctor. X resided in the Western Cape for all his life. He was a Black African Muslim who practiced aspects of African customary law. He was also one of the cultural leaders in the African community. He left behind a gross estate to the value of $R 2200000.00$.

$X$ executed a written will on 30 August 2016. The will satisfied the conditions required for it to be valid in terms of South African law. It was also valid and enforceable in terms of Islamic law. This type of will is referred to hereafter as an "Islamic will". X appointed his wife (C) as the executrix of his estate. The will stated that the liabilities first needed to be deducted from the gross estate before settling the testate and intestate succession claims. The will further stated that the appointed executrix should ascertain whether there were any legal and/or religious liabilities against the estate. The will expressly made mention of any deferred dower, arrear maintenance, and/or contractual debts as examples of legal liabilities in this regard. It also expressly made mention of an unperformed pilgrimage to Makkah (hajj) as an example of a religious liability.

$X$ made several bequests in his will. He bequeathed $1 / 6$ of his net estate to his divorced wife (E). He bequeathed another $1 / 6$ of his net estate to his daughter $(\mathrm{J})$ who was conceived out of wedlock. The will stated that the remainder of his estate should be distributed in terms of the Islamic law of intestate succession. The will further stated that the executrix of the estate must acquire an "Islamic distribution certificate" from a qualified Islamic law expert with a degree in Islamic law in this regard. The certificate must provide the names of his intestate succession beneficiaries at the time of his death in terms of Islamic law. The will did not state the school of law (school) that should be used in this regard. The divorced wife (E) killed $X$. The daughter who was conceived out of wedlock $(J)$ renounced the $1 / 6$ bequest $\mathrm{X}$ made to her. The renouncement was made after $\mathrm{X}$ had died.

The liabilities against the estate were R232 000.00 in total. These included administration costs; funeral costs; an unpaid dower that was due nine years before; an arrear maintenance that was due eight years before; an unperformed pilgrimage owing to God Almighty; and a debt owed to a creditor that was due six years before. There were no other liability claims against the estate. The executrix (C) approached an Islamic law expert for an Islamic distribution certificate as required in terms of the will. She was instructed to depose a next of kin affidavit for the Islamic law expert to draft and issue the Islamic distribution certificate. All supporting documentation, including a certified copy of the death certificate, copy of the last will and testament, marriage certificates, divorce certificates, birth certificates, and any other relevant documents, were required to be submitted with the affidavit. It is interesting to note that similar documents are required by the 
Muslim Judicial Council (SA) before issuing an Islamic distribution certificate to an executor or executrix. ${ }^{3}$

The relatives of $X$ who were stated in the next of kin affidavit were his parents, four spouses whom he had married, a number of descendants, and a number of siblings. The affidavit stated that $X$ left behind both parents and he was conceived in wedlock. His mother is $(A)$ and his father is (B). His father converted to Christianity two years before $X$ died. $X$ married four women during his lifetime. All these marriages were in terms of Islamic law only. The first wife is $\mathrm{C}$. She is also the executrix of the estate. Her marriage to $X$ was intact at the time of his demise. The second wife is (D). D successfully obtained a judicial divorce in the form of a faskh nine months prior to $X$ having died. They subsequently reconciled one month later but did not remarry. The third wife is (E). She is a practising Jewess. $E$ is also the person who killed $X$. The fourth wife is $(F)$. $X$ issued $F$ with an irrevocable divorce one hour prior to dying. His intention was to disinherit her.

$X$ also leaves behind a number of children. They are an adopted daughter (G); a non-biological accepted son in terms of African custom $(\mathrm{H})$; a biological daughter who was conceived out of wedlock by artificial fertilisation (I), a biological daughter who was conceived out of wedlock (J); a cognate grandson $(\mathrm{K})$ whose mother had predeceased $\mathrm{X}$; a legal daughter (L) who was conceived in wedlock but as a result of an adulterous act between the wife of $X$ and another man; and an agnate granddaughter (M). $X$ further left behind a number of siblings, including a full brother who converted to Christianity $(\mathrm{N})$; a full sister $(\mathrm{O})$; and a consanguine brother $(\mathrm{P})$. All the persons mentioned above are Muslim except for his father B (Christian), his divorced wife $\mathrm{E}$ (Jewess), and his full brother N (Christian).

The liquidation and distribution of the estate is now discussed in terms of the abovementioned facts. The issues that will be looked at include the conditions to be complied with before administering an estate, estate liability claims, testate succession claims, and intestate succession claims. Minor comparisons are made between the laws of the two legal systems where deemed relevant.

\section{CONDITIONS TO BE MET BEFORE ADMINISTERING AN ESTATE}

The conditions that must be met before the estate of a person may be deemed a deceased estate is that he must have died or been declared dead by a court of law. X died on 30 August 2017 at 10:00 PM. This was confirmed by a registered medical doctor. His estate fell open at that moment in time. This is also referred to as delatio. It should be noted that the rights of the testate and intestate beneficiaries vest at this time.

3 See Dante "Distribution Certificates (Estates)" (2016) http://mjc.org.za/2016/06/14/ distribution-certificates-estates/ (accessed 2017-10-20). 


\section{CLAIMS AGAINST THE GROSS ESTATE}

The value of the assets in the estate prior to any deductions was R2 200 000.00. This is also referred to as the gross estate. The first claims against the amount would be the liabilities, followed by the testate succession claims, followed by the intestate succession claims. All three claims are present in the scenario.

\section{$4 \quad$ LIABILITY CLAIMS}

A number of liabilities are referred to in the scenario. The total amount of liabilities totalled R232 000.00. This included the funeral costs, the administration costs, the unpaid dower, the unpaid maintenance claim, the contractual claim, and the unperformed pilgrimage. The estate would be considered solvent as the assets exceeded the liabilities by R1 968 000.00.

\section{Administration costs}

Administration costs include funeral costs, estate duty, bank charges, transfer fees, executor's fees, and Master's fees, which are all claims against the estate that are required to be settled in order to successfully liquidate the estate within the South African context. ${ }^{4}$ These claims are not expressly stated in the classical texts governing the laws of succession and administration of estates in terms of the Shaafi'ee and Hanafee schools. They are, however, incidental costs as they are required to be settled in order to successfully liquidate and distribute an estate in terms of South African law.

The funeral costs include all expenses that were directly related to the burial of a deceased Muslim. This claim would be allowed in terms of South African law even if there was no will stating that these costs must be paid. It is interesting to note that the current funeral costs for burying a deceased ranges from R2 500.00 to $R 5000.00 .^{5}$ There is a legal maxim in Islamic law which states that any act needed to fulfil an obligation is in itself an obligation. $^{6}$ These payments must be made to ensure that the creditors as well as the testate and intestate succession beneficiaries receive what is rightfully theirs. There are currently Islamic institutions in South Africa that offer the services of an executor and claim the executor's fees. This has been accepted as standard practice for services rendered. These institutions include Absa Islamic and Albaraka banks.

De Waal and Schoeman-Malan Law of Succession 5ed (2015) 244.

5 Compare Guru "Funerals in South Africa and what they Cost - Muslim Burial Culture" http://compareguru.co.za/news/funeral-customs-in-sa-and-what-they-cost/ (accessed 201701-03). See Hartley "The Cost of Death" (2016) http://www.vocfm.co.za/the-cost-of-death/ (accessed 2017-10-20).

6 Ibn Qudaamah Rawdah Al NaaDhir Wa Jannah Al ManaaDhir Fee Usool Al Fiqh 'Alaa Madh hab Al Imaam Ahmad (1998) vol 1118-120.

7 Absa Bank "Have Peace of Mind with an Islamic Will" https://www.absa.co.za/personal/bank/islamic-banking/islamic-wills/ (accessed 2017-10-20). See also Albaraka Bank "Administration of Estates and Wills" 


\section{Debt}

The other possible liabilities in this scenario include both legal and religious claims against the estate. The arrears dower claim, arrears maintenance claim, and contractual debt claim are the legal claims mentioned in this scenario. These claims are all older than three years and have therefore been prescribed in terms of South African law. Prescription was also applied in the Western Cape High Court in Ryland $v$ Edros where a divorced spouse claimed arrears maintenance. ${ }^{8}$ The divorced spouse claimed for approximately 20 years of arrears maintenance from her former husband to whom she was married in terms of Islamic law. Her claim was based on Islamic law principles. Her claim for maintenance was successful. She could only claim maintenance for up to three years from the date that her claim was served on her former husband, however. ${ }^{9}$ This was due the application of the Prescription Act 68 of $1969 .{ }^{10}$ It is quite interesting to note that the current version of the Muslim Marriages Bill includes a clause that excludes the application of the Prescription Act from Islamic law marriages concluded in terms of the Bill. ${ }^{11}$ The Bill has not yet been enacted and would have no impact on the scenario.

The executrix could argue that these claims have prescribed and are therefore not enforceable and that the creditors should therefore not be paid. The claims have not prescribed in terms of Islamic law and must therefore be paid. X made provision for these claims by empowering his executrix with the authority to settle them. These claims must therefore be settled by the executrix in terms of the provisions in the will. It could be argued that the right to freedom of testation should override the prescription rule.

The unperformed pilgrimage claim is the only religious claim in this scenario. This claim is not automatically enforceable as a liability in terms of South African law. X has, however, made provision for this payment in terms of the will. The religious liability is enforceable in terms of the Shaafi'ee school but not in terms of the Hanafee school. The will does, however, make

http://www.albaraka.co.za/ProductsandServices/Administrationofestatesandwills.aspx

\#Estate (accessed 2017-10-20).

8 The South African law position has been confirmed in Ryland v Edros 1997 (2) SA 690 (C). In this case, the Court recognised some of the consequences that flow from marriages entered into in terms of Islamic law. One of the consequences was a claim for arrears maintenance in terms of the law of contract. It should be noted that the facts in Ryland $v$ Edros supra involved a claim for arrears maintenance subsequent to a divorce. The scenario at hand deals with a claim for arrears maintenance subsequent to death. It should be noted that Ryland $v$ Edros supra is a High Court decision and is binding only in the Western Cape.

9 Ryland $v$ Edros supra 718-719.

10 See s 10(1)(a) of the Prescription Act 68 of 1969 where it states that "(1) [s]ubject to the provisions of this chapter and of Chapter IV, a debt shall be extinguished by prescription after the lapse of the period which in terms of the relevant law applies in respect of the prescription of such debt."

11 See s 11(5) of the 2010 MMB www.gov.za/sites/www.gov.za/files/33946_gen37.pdf (accessed 2017-10-26) where it states that "[a]ny unpaid arrear maintenance, either mutually agreed to or in terms of a court order, which is due and payable to a wife may not be extinguished by prescription, notwithstanding the provisions of the Prescription Act, 1969 (Act No. 68 of 1969), or any other law". 
express reference to the unperformed pilgrimage. It can therefore be assumed that the testator wanted the Shaafi'ee school to apply in this regard. The executrix must therefore settle this claim as per the will by instructing a person to perform the pilgrimage on behalf of $X$. The average package cost for a pilgrimage is approximately R32 $650.00 .^{12}$

\section{TESTATE SUCCESSION CLAIMS}

The remainder of the gross estate in this scenario, after the liabilities have been deducted, is R1 968000.00 . This amount is also referred to as the net estate.

\section{Law of wills}

X executed a Sharee'ah compliant will that satisfied all the South African law requirements for validity. Absa Islamic Bank offers the service of drafting and executing a Sharee'ah compliant will. They charge a nominal fee of R342.00 for the drafting and execution of these wills. ${ }^{13}$ The Muslim Judicial Council, based in the Western Cape, offers this service of drafting and executing a Sharee'ah compliant will.

An Islamic will normally include a clause stating that the residue of the estate must devolve in terms of the Islamic law of succession. An Islamic institution or an Islamic law expert would then be appointed in the will to issue an Islamic distribution certificate. The facts of the scenario did not state who drafted the will. It did, however, state that the Islamic distribution certificate needed to be issued by an Islamic legal expert. This raises the question of delegation of testamentary powers, which is generally not allowed in terms of South African law. There are limited exceptions. The Islamic law expert would not have the authority to draft the Islamic distribution certificate as he or she pleases. He or she must identify the beneficiaries in terms of Islamic law. This type of certificate was accepted by the Master of the High Court in Moosa NO v Harnaker on 14 September $2017 .{ }^{14}$ The Court noted that the will stated that the estate should devolve in terms of Islamic law and that an Islamic distribution certificate from the Muslim Judicial Council shall be binding in this regard. The Islamic distribution certificate was executed by the Muslim Judicial Council in terms of the will. ${ }^{15}$ It is interesting to note that the validity of the certificate was not disputed by the Master of the High Court and the Registrar of Deeds. The Court also did not comment on it.

12 Al Anwar Express "Swissotel Al Maqam Package 2017" http://alanwarexpress.co.za/tours/ swissotel-al-maqam-package/ (accessed 2017-10-20).

13 Absa Bank https://www.absa.co.za/personal/bank/islamic-banking/islamic-wills/. See also Albaraka Bank http://www.albaraka.co.za/ProductsandServices/Administrationof estatesandwills.aspx\#Estate.

14 Moosa NO v Harnaker 2017 (6) SA 425 (WCC) par 7.

15 Ibid.

16 Moosa NO v Harnaker (ZAWHC) unreported case no 400/17 (14 September 2017). 
It should be noted that, as a holder of an Islamic law degree, the author has also issued a few Islamic distribution certificates. The certificates that he has issued in the Western Cape were accepted by the Master of the High Court and the estates have since been finalised. It is interesting to note that the Muslim Judicial Council (SA) currently charges a fee of R300.00 for issuing an Islamic distribution certificate and that it takes approximately seven days for them to issue the certificate. ${ }^{17}$ It could therefore be said that these certificates are generally accepted by the Master of the High Court. It should be noted that the validity of a clause in an Islamic will that requires an Islamic law expert to issue an Islamic distribution certificate has (to date) not been considered by the courts in light of the rule that prohibits delegation of testamentary powers. The rule is also not applied by the Master's Office in this regard as stated above. There is, however, no obvious reason for ignoring the rule. It could be argued that in the case of Islamic wills, the common law has been developed through custom as envisaged in Breda $v$ Jacobs. ${ }^{18}$

\section{Testate succession disqualifications and substitution}

$X$ bequeathed $1 / 6$ of his net estate to his Jewish wife $(E)$. She is disqualified from inheriting as an intestate beneficiary due to her following a different religion from that of $X$. This raises the question of discrimination based on religion..$^{19} \mathrm{E}$ is, however, eligible to inherit as a testate beneficiary as she is not an inheriting intestate beneficiary. ${ }^{20} \mathrm{E}$ is, however, also the person who unlawfully killed X. E is therefore disqualified from inheriting the $1 / 6$ in terms of South African law. $E$ is also disqualified from inheriting the $1 / 6$ in terms of the Hanafee school. The majority opinion within the Shaafi'ee school states that a murderer would be eligible to inherit as a testate beneficiary but not as an intestate beneficiary. The minority opinion within the Shaafi'ee school

17 Dante http://mjc.org.za/2016/06/14/distribution-certificates-estates/.

18 See Breda $v$ Jacobs 1921 AD 330. The court held that the requirements for proving a custom are that the custom must have been in existence for a long period, the relevant community must generally observe the custom, the custom must be reasonable, and the content of the custom must be certain and clear. See also Himonga and Nhlapo (eds) African Customary Law in South Africa - Post Apartheid and Living Law Perspectives (2015) 30, See also Bennet Customary Law in South Africa (2004) 11 where it states that "a local custom may be deemed obligatory, and thus part of the legal code, once witnesses attested to the existence of a repeated practice that was reasonable, certain, uniform and well established".

19 See s 9(3) of the Constitution of the Republic of South Africa, 1996 where it states that "[t]he state may not unfairly discriminate directly or indirectly against anyone on one or more grounds, including race, gender, sex, pregnancy, marital status, ethnic or social origin, colour, sexual orientation, age, disability, religion, conscience, belief, culture, language and birth".

20 A person who inherits as an intestate beneficiary cannot inherit as a testate beneficiary unless the remaining intestate beneficiaries consent thereto after the deceased has passed on. $E$ is disqualified from inheriting as an intestate beneficiary due to her religion. Difference of religion does not disqualify a person from inheriting as a testate beneficiary. Murder is different as it is a disqualification in terms of law of testate succession as well as the law of intestate succession in terms of the Hanafee school. Murder is not a testate succession disqualification in terms of the Shaafi'ee school. 
states that a murderer would be disqualified from inheriting as an intestate beneficiary. It could be argued that Islamic law should take preference over the South law as the will is based on Islamic law principles. It is, however, not certain whether Islamic law would override the South African law principle in this regard. The question then arises as to which law should apply in the scenario. This is, in the final analysis, left up to the Islamic law expert to decide. For the purposes of this discussion, it will be assumed that the Islamic law expert applied the minority opinion found within the Shaafi'ee school, which states that a murderer is disqualified from inheriting as a testate beneficiary.

\section{Testate succession exclusions}

$X$ bequeathed $1 / 6$ of his net estate to his daughter $(\mathrm{J})$ who was conceived out of wedlock. $X$ also leaves behind a totally excluded cognate grandson (K). J would inherit the $1 / 6$ in terms of both the Shaafi'ee and Hanafee schools. However, $\mathrm{K}$ could totally exclude $\mathrm{J}$ from inheriting in terms of the compulsory bequest rule that is applied in Syria. K would then inherit the share of his predeceased mother, which is $1 / 3$. He would inherit the $1 / 3$ as a compulsory bequest. The $1 / 3$ would take precedence over the $1 / 6$ bequest to J.

The question as to whether the compulsory bequest rule would apply in this scenario is solely dependent on whether or not the Islamic law expert would include $\mathrm{K}$ as the recipient of the 1/3 in terms of the Islamic law reform as applied in Syria and Egypt. These two countries also have followers of the Shaafi'ee school. It could be argued that the practice in these two countries has not been incorporated into the Islamic law applied by Muslims in South Africa. This type of argument was also made in Ryland $v$ Edros with regards to the application of the Malaysian custom of harta sepencarian to South African Muslims. ${ }^{21}$ Bequests should not exceed $1 / 3$ of the net estate. The Islamic law expert cannot change the bequest made to $\mathrm{J}$ as he has not been empowered to do so. The Islamic law expert could, however, include $\mathrm{K}$ as a compulsory beneficiary of $1 / 6$ only. The bequest would be within the $1 / 3$ limitation. It would be $1 / 6$ as an optional bequest in terms of the will, and $1 / 6$ as a compulsory bequest. This would then be a reformed version of the compulsory bequest within the South African context. It should be noted that there is nothing in this scenario that prevents the Islamic law expert from applying the compulsory bequest rule regarding the Islamic distribution certificate. This scenario is, therefore, different to the situation found in Ryland $v$ Edros. ${ }^{22}$ It will, however, be assumed for purposes of the discussion, that $\mathrm{K}$ was not included in the Islamic distribution certificate.

\footnotetext{
21 The South African law position has been confirmed in Ryland $v$ Edros supra 717 where the court held that the "evidence falls far short of proving that a custom similar to the Malay adat relating to harta sepencarian prevails among the Islamic community in the Western Cape".

22 Ryland v Edros supra.
} 


\section{Testate succession limitations}

$X$ bequeathed the remainder of his net estate in terms of the Islamic law of intestate succession. He was empowered to do this is in terms of the principle of freedom of testation. The principle is restricted in terms of the South African Constitution which prohibits unfair discrimination. ${ }^{23}$ Possible constitutional violations found within Islamic law of intestate succession are highlighted in 6.1 and 6.2 of this article.

\section{Testate succession adiation, repudiation, substitution and collation}

Adiation is when an appointed testate beneficiary accepts the benefit in terms of a will. $X$ bequeathed $1 / 6$ of the net estate $(1 / 6 \times \mathrm{R} 1968000.00=$ R328 000.00) to his divorced wife (E). He also bequeathed 1/6 thereof $(1 / 6 x$ R1 $968000.00=R 328000.00)$ to his biological daughter $(\mathrm{J})$, who was conceived out of wedlock. E was disqualified due to having unlawfully killed $X$. Her benefit would be redirected into the net estate.

The daughter $(\mathrm{J})$ conceived out of wedlock repudiated the benefit. The repudiated benefit would be inherited by the surviving spouses of $X$ in terms of South African law. The $1 / 6$ of the net estate $(1 / 6 \times R 1968000.00=$ R328 000.00) must be redirected back into the net estate in terms of Islamic law. Nothing prevents $\mathrm{J}$ from accepting the benefit and then gifting it in favour of the surviving spouses. The distribution would then be correct in terms of both Islamic law and South African law.

It could be argued that $X$ accepted the South African law position regarding representation as he has not made provision for a different mode of substitution. It could also be argued that $X$ was unaware that $J$ would repudiate the benefit. A solution to this type of situation would be for a testator or testatrix to expressly state in his or her will that all matters concerning interpretation should be handled strictly in terms of Islamic law and that a qualified Islamic law expert should issue a ruling in this regard.

\section{INTESTATE SUCCESSION CLAIMS}

The remainder of the net estate, after the value of all bequests have been deducted, constitutes the intestate estate. The intestate inheritance in this scenario is R1 968000.00 . This part of the estate must be distributed to the intestate beneficiaries as provided for in the Islamic distribution certificate. The following sections discuss the provisions that govern how the intestate beneficiaries as provided for in the Islamic distribution certificate are determined from the surviving relatives. The possible constitutional challenges to the Islamic law provisions are highlighted where relevant. The discussion is based on the distribution in terms of the Hanafee and Shaafi'ee schools. Other schools are mentioned where deemed fit.

23 See s $9(4)$ of the Constitution where it states that "[n]o person may unfairly discriminate directly or indirectly against anyone on one or more grounds in terms of subsection (3)". 


\section{Intestate succession ties}

The intestate succession ties looked at in this section are those in terms of Islamic law. The three relevant ties in this scenario are consanguinity ties, affinity ties, and quasi-consanguinity ties. $X$ was conceived in wedlock. Both his parents $(A$ and $B$ ) are related to him through blood. $X$ has also concluded affinity ties with four women $(C, D, E$, and $F)$. $X$ further has consanguinity ties with his biological children ( $\mathrm{I}$ and $\mathrm{J}$ ), his biological grandchildren ( $\mathrm{K}$ and $\mathrm{M}$ ) and his siblings ( $\mathrm{N}, \mathrm{O}$, and $\mathrm{P})$. $\mathrm{X}$ also has a quasi-consanguinity tie with his son (L) who was born as a result of an adulterous act by one of his wives.

The adopted daughter $(\mathrm{G})$ and the accepted son $(\mathrm{H})$ do not have intestate ties with $X$. $G$ is regarded as the child of $X$ for all legal purposes in terms of South African law. $G$ is not regarded as the daughter of $X$ for any legal purposes in terms of Islamic law. Her rights and duties remain with her biological parents in terms of Islamic law. G could possibly challenge the constitutionality of the Islamic law position based on discrimination. ${ }^{24}$

The situation of the non-biological accepted son $(\mathrm{H})$ is quite interesting. It could be argued that this child is the son of $X$ as he satisfies the requirements in terms of the Reform of the Customary Law of Succession and Regulation of Related Matters Act. X was a cultural leader who practised aspects of African culture. $\mathrm{He}(\mathrm{H})$ is, however, not deemed a son of $\mathrm{X}$ in terms of Islamic law as there is no consanguinity tie present. He will not be listed as one of the intestate beneficiaries in the Islamic distribution certificate. This raises the question of discrimination based on birth. ${ }^{25}$

\section{Intestate succession disqualifications and substitution}

The parents, children, grandchildren, and spouses of $X$ have intestate succession ties. These persons would inherit only if they are neither disqualified nor totally excluded from inheriting. The father $(B)$ is disqualified from inheriting due to him following a different religion from that of $X$. This raises the question of discrimination based on religion. ${ }^{26}$ The revocably divorced Jewish wife $(E)$ would not inherit as she is disqualified from inheriting as a surviving spouse as she is of a different religion to X. She has also been disqualified from inheriting the testate benefit due to her having murdered $X$. It is interesting to note that she is eligible to inherit $1 / 6$ of the net estate $(1 / 6 \times R 1968000.00=R 328$ 000.00) in terms of the Shaafi'ee school but not in terms of the Hanafee school. There would be no issue with

24 See s 9 of the Constitution of the Republic of South Africa, 1996 where it states that "(3) [t]he state may not unfairly discriminate directly or indirectly against anyone on one or more grounds, including race, gender, sex, pregnancy, marital status, ethnic or social origin, colour, sexual orientation, age, disability, religion, conscience, belief, culture, language and birth. (4) No person may unfairly discriminate directly or indirectly against anyone on one or more grounds in terms of subsection (3)".

26 Ibid.

Ibid. 
a legal expert using the Hanafee school in this regard as the will does not require him to follow a specific school. It will be assumed for purposes of this scenario that the Hanafee school opinion was applied. The intestate succession disqualification of $B$ and $E$ raises the question of discrimination based on religion. ${ }^{27}$ Discrimination based on religion is automatically deemed unfair in terms of s 9(3) of the Constitution. ${ }^{28}$

$X$ married four wives during his lifetime. They included three Muslim women (C, D, and F) and one Jewish woman (E). C was the only wife who was not subject to a divorce. D obtained a judicial divorce in the form of a faskh nine months before $X$ died. The faskh brought the marriage to an end irrevocably even though the couple reconciled during the waiting period. A new marriage was required if they wanted to live as husband and wife. $D$ is disqualified from inheriting in her capacity as a surviving spouse in terms of Islamic law as they did not remarry. It is interesting to note that the Western Cape High Court incorrectly stated in the Hassam $v$ Jacobs case that a faskh is revocable during the waiting period. ${ }^{29}$ D's name would therefore not appear on the Islamic distribution certificate as she would have been disqualified from inheriting as a surviving spouse.

$\mathrm{X}$ issued $\mathrm{F}$ with an irrevocable divorce one hour prior to dying. The facts of the scenario state that his intention was to disinherit her. The divorce is disregarded due to his unlawful intention. This is an opinion within the Hanafee school. F would not inherit in terms of the Shaafi'ee school as the divorce was irrevocable. The context of the will seems to indicate that the Shaafi'ee school was intended as it referred to deduction of religious liabilities claims against the estate. This is an opinion within the Shaafi'ee school. There is, however, no direct instruction in this regard that the Shaafi'ee school should apply. There is also nothing preventing the legal expert drafting the Islamic distribution certificate from using the opinion within the Hanafee school in this regard. For the purposes of this discussion, It will be assumed that the Shaafi'ee school opinion was used.

The biological daughter (I) who was conceived out of wedlock and by artificial insemination is disqualified from inheriting. The biological daughter (J) who was conceived out of wedlock is also disqualified from inheriting. This raises the question of discrimination based on birth. Discrimination based on these grounds is automatically deemed unfair in terms of s 9(3) of

\footnotetext{
Ibid.

See s 9(5) of the Constitution of the Republic of South Africa, 1996 where it states that "[d]iscrimination on one or more of the grounds listed in subsection (3) is unfair unless it is established that the discrimination is fair".

29 Moosa and Abduroaf "Faskh (Divorce) and Intestate Succession in Islamic and South African Law: Impact of the Watershed Judgment in Hassam $v$ Jacobs and the Muslim Marriages Bill" in De Waal and Paleker South African Law of Succession and Trusts - The Past Meeting the Present and Thoughts for the Future (2014) 162 where it states that "[t]his article contends that the decision of the Cape Provincial Division of the High Court (now the Western Cape High Court) in that case may be criticised for misapplying the Islamic law (Shari'a) which regulates matters of MPL, particularly its provisions pertaining to the form of judicial divorce known as 'faskh'".
} 
the Constitution. ${ }^{30}$ The full brother $(\mathrm{N})$ is disqualified from inheriting due to him following a different religion from that of $X$. This disqualification raises the constitutional question of discrimination based on religion.

\section{Intestate succession exclusions}

The remaining intestate beneficiaries who have not been disqualified are the mother $(A)$, the first wife $(C)$, the fourth wife $(F)$, the cognate grandson $(K)$, the daughter $(L)$ who was conceived in wedlock as a result of adultery between the wife of $X$ and another person, the agnate granddaughter (M), the full sister $(\mathrm{O})$, and the consanguine brother $(\mathrm{P})$. The provisions found in the law of exclusion could still apply to any of these persons.

The cognate grandson $(K)$ is totally excluded from inheriting as an intestate beneficiary by the mother $(A)$, by the daughter $(L)$ who was conceived in wedlock but as a result of an adulterous act between the wife of $X$ and another person, by the agnate granddaughter $(M)$, by the full sister $(\mathrm{O})$, and by the consanguine brother $(\mathrm{P})$. The cognate grandson $(\mathrm{K})$ is a distant kindred beneficiary and would inherit only in the event where there are no residuary beneficiaries and no return beneficiaries present. The intestate beneficiaries in this scenario include both return beneficiaries as well as one residuary beneficiary. It should be noted that residuary beneficiaries take priority over return beneficiaries.

The consanguine brother $(\mathrm{P})$ is totally excluded by the full sister $(\mathrm{O})$. This is quite interesting to note as a female is totally excluding a male from inheriting. It is also interesting to note that the Islamic law position is more favourable towards the female sibling in this regard. It should, however, be noted that the full sister has a stronger intestate tie to the deceased than the consanguine brother. It could be argued that the full sister (female) inherits more favourably in this scenario because she has a stronger intestate succession tie to the deceased. The consanguine brother inherits less favourably because he has a weaker intestate succession tie to the deceased.

There is only one intestate beneficiary who is partially excluded in this scenario. The mother is partially excluded from inheriting $1 / 3$ of the intestate inheritance $(1 / 3 \times R 1968000.00=R 656000.00)$ as a sharer beneficiary by the daughter $(\mathrm{L})$. She now inherits $1 / 6$ of the intestate inheritance $(1 / 6 \mathrm{x}$ R1 $968000.00=$ R328 000.00) as a sharer beneficiary. ${ }^{31}$ It should be noted that a mother is one of the primary beneficiaries that is never subject to total exclusion.

30 See s 9(3) of the Constitution of the Republic of South Africa, 1996 where it states that "[t]he state may not unfairly discriminate directly or indirectly against anyone on one or more grounds, including race, gender, sex, pregnancy, marital status, ethnic or social origin, colour, sexual orientation, age, disability, religion, conscience, belief, culture, language and birth. (4) No person may unfairly discriminate directly or indirectly against anyone on one or more grounds in terms of subsection (3)."

31 See Khan The Noble Qur'an - English Translation of the Meanings and Commentary $1404 \mathrm{H}$ (4) 11 where it states that "[f]or parents, a sixth share of inheritance to each if the deceased left children; if no children, and the parents are the (only) heirs, the mother has a third; if the deceased left brothers or (sisters), the mother has a sixth ..." 


\section{Intestate succession limitations}

There are no direct limitations that apply in the Islamic law of intestate succession. There is, however, one indirect limitation. The law of intestate succession would apply only where the liabilities have not depleted the gross estate. The liabilities in this scenario have not depleted the gross estate. The remainder in this scenario is R1 968000.00 .

The remaining intestate beneficiaries, who are neither disqualified nor totally excluded from inheriting as intestate beneficiaries, are his mother $(A)$, the first wife $(C)$, the fourth wife $(F)$, the cognate grandson $(K)$, the biological daughter (L) who was conceived in wedlock but as a result of an adulterous act between the wife of $X$ and another man, his agnate granddaughter (M), and his full sister $(\mathrm{O})$.

\section{Intestate succession adiation, repudiation, substitution and collation}

Adiation is not required in terms of the Islamic law of intestate succession. Repudiation is also not possible. None of the intestate succession beneficiaries in this example have repudiated. It should be noted that the doctrine of collation does not find application in Islamic law.

\section{Categories of intestate succession beneficiaries and their shares}

The remaining intestate beneficiaries who are neither disqualified, nor totally excluded from inheriting as intestate beneficiaries, are the mother $(A)$, the first wife $(C)$, the fourth wife $(F)$, the daughter $(L)$ who was conceived in wedlock but as a result of an adulterous between the wife of $X$ and another man, his agnate granddaughter (M), and the full sister $(\mathrm{O})$.

The two classes of intestate beneficiaries in this scenario are sharer beneficiaries and a residuary beneficiary. The mother (A), first wife (C), fourth wife $(F)$, daughter (L) who was conceived as a result of adultery between the wife of $\mathrm{X}$ and another man, and his agnate granddaughter (M) are sharer beneficiaries. The full sister is the only residuary beneficiary.

The mother would inherit $1 / 6=8 / 48,{ }^{32}$ the first wife would inherit $1 / 16=$ $3 / 48,{ }^{33}$ the fourth wife would inherit $1 / 16=3 / 48,{ }^{34}$ the daughter would inherit $1 / 2=24 / 48,{ }^{35}$ the agnate granddaughter would inherit $1 / 6=8 / 48$, and the full sister would inherit the remaining $2 / 48$.

32 Ibid.

33 See Khan The Noble Qur'an - English Translation of the Meanings and Commentary $1404 \mathrm{H}$ (4) 12 where it states that "[i]n that which you leave, their (your wives) share is a fourth if you leave no child; but if you leave a child, they get an eighth of that which you leave after payment of legacies that you may have bequeathed or debts ..."

34 Ibid.

35 See Khan The Noble Qur'an - English Translation of the Meanings and Commentary $1404 \mathrm{H}$ (4) 11 where it states that 'Allah commands you as regards your children's 
The mother would inherit $8 / 48 \times R 1968000.00=R 3280000.00$, the first wife would inherit $3 / 48 \times R 1968000.00=R 123000.00$, the fourth wife would inherit $3 / 48 \times R 1968000.00=R 123000.00$, the daughter would inherit $24 / 48 \times R 1968000.00=R 984000.00$, the agnate granddaughter would inherit $8 / 48 \times R 1968000.00=R 328000.00$, and the full sister would inherit the remainder which is $2 / 48 \times \mathrm{R} 1968000.00=\mathrm{R} 82000.00$.

\section{Position of females in this example}

The scenario that was looked at in this article was where $X$ died and left a number of relatives behind. They are five males and 11 females. None of the five males inherited in this example, whereas six of the 11 females inherited.

The relatives in this example were subject to the law concerning inheritance ties, disqualifications, as well as exclusions. Both the adopted daughter $(\mathrm{G})$ as well as the non-biological accepted son $(\mathrm{H})$ did not inherit due to there being no intestate succession tie present. The father $(B)$ and the Jewish wife $(E)$ were both disqualified from inheriting due to being of a different religion from that of $X$. The mother $(A)$ was the only intestate beneficiary who was partially excluded. It can clearly be seen that the Islamic law of succession favoured the females in this scenario.

\section{CONCLUSION}

This article has looked at the application of the Islamic law of succession within the South African context by means of a will. The findings have shown that the application is possible. It is generally argued that the Islamic law of succession discriminates against females. The article has shown that this is not necessarily the case. This scenario has shown that the females in this scenario would inherit the complete estate even though there are two males present who were not disqualified. It could therefore be argued that the grounds for the discrimination would be based on the strength of the intestate succession tie between the deceased and the intestate beneficiary. It is for this reason that the full sister inherited the residue to the exclusion of the full brother. It is also for this reason that the cognate granddaughter inherited to the exclusion of the agnate grandson. It must, however, be noted that male intestate beneficiaries would inherit more favourably than females based on a different scenario. The article has shown that a general clause in a will stating that the Islamic law of succession must apply to the will is problematic in instances where there are differences of opinion within Islamic law. This was specifically seen in the irrevocable divorce during death illness.

(inheritance); to the male, a portion equal to that of two females; if (there are) only daughters, two or more, their share is two thirds of the inheritance; if only one, her share is half ..." 